\title{
EXPERIMENTAL EVALUATION OF THE ACTIVITY OF THE PRODUCT MEFLOCHINE AGAINST CORONAVIRUS SARS-COV-2
}

Filin $\mathrm{KN}^{1}$, Berzin $\mathrm{IA}^{2}$, Bykov VN1', Gladkikh VD'1, Loginova SYa³, Savenko SV³ , Schukina VN³

${ }^{1}$ Federal State Unitary Enterprise Research \& Production Center "Pharmaceutical Protection" of Federal Medical Biological Agency, Khimki, Russia

${ }^{2}$ Federal Medical and Biological Agency, Moscow, Russia

${ }^{3}$ Federal State Budgetary Institution "48 Central Research Institute" of the Ministry of Defense of the Russian Federation, Sergiev Posad-6, Russia

When evaluating the effectiveness of the drug Mefloquine against SARS-CoV-2 coronavirus, in vitro experiments examined its toxicity for African green monkey kidney cell culture - Vero C1008, as well as antiviral activity against SARS-CoV-2, which was evaluated by suppressing the cytopathic effect the virus. A study of the toxicity of the drug Mefloquine showed that the concentration at which the drug exerts a cytopathic effect against $50 \%$ of Vero $\mathrm{C} 1008 \mathrm{cells}$ is $4.5 \mathrm{\mu g} / \mathrm{ml}$. The maximum tolerated concentration (MTD) of Mefloquine is $2.25 \mu \mathrm{g} / \mathrm{ml}$. A study of the effectiveness showed that 1 day after infection, the antiviral effect of Mefloquine was recorded when the drug was added 24 hours and 1 hour before infection with SARS-CoV-2, as well as when it was added 1 hour after infection, the cell culture was already at a concentration of $0.5 \mu \mathrm{g} / \mathrm{ml}$ Mefloquine at a concentration of $2 \mu \mathrm{g} / \mathrm{ml}$, added to the Vero C1008 cell culture 1 hour after the introduction of SARS-CoV-2, completely blocked the action of the virus for 2 days after infection.

Keywords: coronavirus, COVID-19, SARS-CoV-2, SARS-COV-2, Mefloquine, antiviral activity

Received: 25.06.2020 Accepted: 17.07.2020 Published online: 09.08.2020

DOI: $10.47183 /$ mes.2020.006

\section{ЭКСПЕРИМЕНТАЛЬНАЯ ОЦЕНКА АКТИВНОСТИ ПРЕПАРАТА МЕФЛОХИН В ОТНОШЕНИИ КОРОНАВИРУСА SARS-COV-2}

\author{
К. Н. Филин ${ }^{1}$, И. А. Берзин², В. Н. Быков¹, В. Д. Гладких , С. Я. Логинова ${ }^{3}$, С. В. Савенко ${ }^{3}$ В. Н. Щукина \\ Федеральное государственное унитарное предприятие Научно-производственный центр «Фармзащита» Федерального медико-биологического агентства, \\ Химки, Россия \\ 2 Федеральное медико-биологическое агентство, Москва, Россия \\ ${ }^{3}$ Федеральное государственное бюджетное учреждение «48 Центральный научно-исследовательский институт» Министерства обороны Российской \\ Федерации, Сергиев Посад-6, Россия
} для культуры клеток почки африканской зеленой мартышки - Vero C1008, а также противовирусная активность в отношении SARS-Cov-2, которую оценивали по подавлению цитопатического действия вируса. Изучение токсичности препарата Меслохин показало, что концентрация, в которой препарат проявляет цитопатическое действие в отношении 50 \% клеток Vero C1008 (ЦПД50), составляет 4,5 мкг/мл. Максимальная переносимая концентрация (МПК) Мефлохина составляет 2,25 мкг/Мл. Изучение эффективности показало, что через 1 сут после инфицирования противовирусное действие Мефлохина регистрировали при внесении препарата за 24 ч и 1 ч до заражения SARS-CoV-2, а также при его добавлении через 1 ч после инфицирования культуры клеток уже в концентрации 0,5 мкг/Мл. Мефлохин в концентрации 2 мкг/мл, добавленный к культуре клеток Vего С1008 через 1 ч после внесения SARS-CoV-2, полностью блокировал действие вируса в течение 2-х сут после инфицирования.

Ключевые слова: коронавирус, SARS-CoV-2, COVID-19, SARS-COV-2, Мефлохин, противовирусная активность

Статья получена: 25.06.2020 Статья принята к печати: 17.07.2020 Опубликована онлайн: 09.08.2020

DOI: $10.47183 /$ mes.2020.006

Coronaviruses (Coronaviridae) are RNA viruses that can infect humans and some animals. In human beings, coronaviruses can cause a range of diseases, from mild acute respiratory infections to severe acute respiratory syndrome (SARS). Currently, there are four coronaviruses (HCoV-229E, -OS43, -NL63 and -HKU1) known to circulate year-round and cause acute respiratory viral infections. As a rule, these infections translate into mild and moderate damage to the upper respiratory tract (URT) [1].

Until 2002, coronaviruses were regarded as pathogens causing URT diseases that extremely rarely ended in death. At the end of 2002, the SARS-CoV coronavirus was registered. It is the causative agent of SARS, severe acute respiratory syndrome. During this epidemic, over 8000 cases were registered in 37 countries, of which 774 were fatal. Since 2004, no new cases of SARS caused by SARS-CoV have been registered [2].

In 2012, the world encountered MERS-CoV, a new coronavirus causing Middle East respiratory syndrome. There have been 2494 cases of this infection registered since 2012, with 858 of them fatal. Geographically, all these cases were associated with the Arabian Peninsula. Currently, MERS-CoV continues to circulate and cause new cases of the disease [3, 4].
In December 2019, a new disease (that was later named COVID-19) was registered in Wuhan, Hubei province, China. The causative agent of this disease is SARS-CoV-2, a new coronavirus. COVID-19 posed new healthcare challenges; in particular, it called for rapid testing techniques and clinical case management tactics [5]. The currently available epidemiological, clinical, prevention and treatment-related information on COVID-19 is limited and inconsistent. The virus was put into the II pathogenicity group, like some other representatives of this genera (SARS-CoV-1, MERS$\mathrm{CoV}$ ). The most common clinical manifestation of the new variant of coronavirus infection is pneumonia, although a significant number of patients have developed acute respiratory distress syndrome.

Chloroquine and hydroxychloroquine, derivatives of quinoline, are the drugs selected for 2019-nCoV therapy [6]. Previously, antiviral activity of chloroquine and hydroxychloroquine against SARS-CoV was demonstrated in cell culture studies [7]. Chloroquine was about fivefold more active than hydroxychloroquine (EC50 in cell culture was $6.5 \pm 3.2 \mu \mathrm{M}$ and $34 \pm 5 \mu \mathrm{M}$, and the selectivity index was $->15$ and $>3$, respectively). Chloroquine was found even more active against the HCoV-OC43 strain (the causative agent of SARS). Its viral replication suppression $\mathrm{EC}_{50}$ was $0.306 \pm 0.091 \mu \mathrm{M}$. 
In experiments on mice, it was established that a $15 \mathrm{mg} / \mathrm{kg}$ dose of chloroquine (about $80 \mathrm{mg}$ for human beings) ensured survival of mice infected with 103 copies of HCoV-OC43 [8]. Chloroquine was also found to produce an effect associated with MERS virus replication blocking at concentrations of 3-8 $\mu \mathrm{M}$ [9].

An in vitro comparative study of antiviral activity of chloroquine and hydroxychloroquine [10] yielded dose-effect curves for four different multiplicities of infection (MOI) by counting viral RNA copies in cell supernatant 48 hours after infection. The preparations were introduced into the cell culture 1 hour before the virus.

Depending on the infective dose, hydroxychloroquine's $\mathrm{EC}_{50}$ was 4.51-12.96 $\mu \mathrm{M}$. Cytotoxic dose of hydroxychloroquine in cell culture was more than 100 times higher than the average effective dose against the virus.

In another study [11], at $\mathrm{MOI}=0.01$ and therapeutic use of hydroxychloroquine (it was introduced into the medium 2 hours after incubation of the cell culture with viral particles at $37^{\circ} \mathrm{C}$ ), its $\mathrm{EC}_{50}$ after 24 hours was $6.14 \mu \mathrm{M}(2060 \mu \mathrm{g} / \mathrm{ml})$, after $48 \mathrm{~h}-$ $0.72 \mu \mathrm{M}(258 \mu \mathrm{g} / \mathrm{ml})$.

These drugs, along with other medicines, were included in the $5^{\text {th }}$ and $6^{\text {th }}$ editions of the COVID-19 Prevention, Diagnostics and Treatment Guidelines published in China in January-February 2020. Hydroxychloroquine was included in the COVID-19, New Coronavirus Infection Interim Prevention, Diagnostics and Treatment Guidelines (versions 4-6) published by the Ministry of Health of the Russian Federation in 2020.

Mefloquine is another antimalarial drug that can potentially be used to treat the SARS-CoV-2 infection. The drug was developed to treat forms of malaria resistant to chloroquine and hydroxychloroquine.

Research into Mefloquine's capability to fight viruses is limited. Nevertheless, it was found to show antiviral activity against Ebola [12], Dengue and Zika viruses [13]. The activity of Mefloquine against various coronaviruses was discovered through in vitro research. Comparative studies that modeled infecting a cell culture with FCoV (feline coronavirus) have shown chloroquine and Mefloquine among the most active drugs out of 19 preparations researched. The antiviral activity of Mefloquine is $2-5$ times higher than that of chloroquine, and its average effective dose, which suppresses the cytopathic effect of the virus in cell culture, was 7.5-8.31 $\mu \mathrm{M}$. The average effective viral replication suppressing dose was $4.43-7.36 \mu \mathrm{M}$ [14]. When combined with interferon, Mefloquine becomes even more potent against viruses [15].

Mefloquine was also found effective against the 2019-nCoV coronavirus. The drug was discovered to block the coronavirus' cytopathic effect in a cell culture and prevent its replication in concentrations of no more than $10 \mu \mathrm{M}(4 \mu \mathrm{g} / \mathrm{L})$ [16]. However, no effort was made to determine the average effective dose of Mefloquine more accurately.

\section{MATERIALS AND METHODS}

We used samples from three lines of Mefloquine (№ 010719, № 020719, № 030719) developed at the Farmzaschita R\&D and production center, Federal state unitary company under the Federal Medical-Biological Agency of Russia. The virus used was variant B of SARS-nCoV, obtained in 2020 from Vector Virology and Biotech Research Center (Federal State Budgetary Institution under Rospotrebnadzor) without isolation data; the variant is stored in the Specialized collection of the $48^{\text {th }}$ Central Research Institute, Federal State Budgetary Institution under the Ministry of Defense of the Russian Federation. For the experimental stage, we used Vero C1008, a permanent culture of African green monkey kidney cells. Eagle's minimal essential medium (MEM) in Hanks saline solution containing 7.5\% and $2 \%$ fetal calf serum, respectively, were used as growth and maintenance cultures.

Biological properties of the SARS-CoV-2 pathogen were assessed by titrating a virus containing suspension in a Vero C1008 cell culture relying on the cytopathic action of the virus.

The cytotoxicity of the Mefloquine samples was assessed by visual observation of the state of Vero $\mathrm{C} 1008$ cell culture with the help of a light microscope at low magnification. Drug concentrations that had cytopathic effect on the cells (destruction of cell monolayer and their overall destruction as confirmed through visual observation) were considered toxic. At the same time, we determined the maximum tolerated dose (MTD), i.e. concentration that did not destroy the cell culture used. In determining the MTD, the optimal time of contact between the studied compound and the cell culture corresponded to the cell cultures' maximum functioning period (4 days on average) [17-19].

We followed recommendations released by the Scientific Centre for Expert Evaluation of Medicinal Products (Federal State Budgetary Institution under the Ministry of Health and Social Development of Russia) in assessment of antiviral efficacy of the experimental substances. The antiviral efficacy of Mefloquine was assessed when its tenfold concentration was administered, a concentration that has a 50\% cytopathic effect (10 CPE50) before infection (1 hour and 24 hours) and 1 hour after infection. The effect on cytopathogenicity of the virus was assessed 24 hours and 48 hours after infection. Monolayer was registered completely destroyed after 48 hours, and after 24 hours we observed cell destruction in $75 \%$ of cases. For each Mefloquine concentration investigated, we used 4 tubes containing a mono-layer of cells; the number of independent experiments was three, which makes the sum total of the tubes twelve. Virus cytopathogenicity inhibition coefficient (IC, \%) allowed assessment of the preparations' efficacy. This coefficient was calculated with the help of the following formula:

$$
I C=\frac{A_{\text {kontr }}-A_{o p}}{A_{\text {kontr }}} \cdot 100 \%
$$

where $A_{\text {kontr }}$ is biological activity of the virus, determined in cells without introduction of the chemical drug; $A_{o p}$ is biological activity of the virus in cells with introduction of the chemical drug (CPE).

The results were statistically processed using Microsoft Office Excel 2007.

\section{RESULTS AND DISCUSSION}

\section{Infecting preparations}

To prepare the SARS-CoV-2 virus, variant $B$, infecting preparation, we used the Vero $\mathrm{C} 1008$ cell culture. A cell suspension with the density of 200 thousand/ml was introduced into sterile plastic cell culture flasks, incubated for 24 hours in a $\mathrm{CO}_{2}$ incubator $\left(5 \% \mathrm{CO}_{2}\right.$ at $\left.37.0 \pm 0.5^{\circ} \mathrm{C}\right)$ until a continuous monolayer was formed, as registered at low magnification of a light microscope. The virus culture was bred on a growth medium. The multiplicity of infection was 1 PFU per cell. The virus adsorption procedure lasted for 60 minutes at $37.0 \pm 0.5^{\circ} \mathrm{C}$. When adsorption was over, we removed the inoculum, washed cells in three volumes of MEM and added 7-8 $\mathrm{ml}$ of fresh growth medium containing $2 \%$ fetal bovine serum to each vial. Flasks with the infected cell culture monolayer were placed in 
a $\mathrm{CO}_{2}$ incubator $\left(5 \% \mathrm{CO}_{2}\right.$ at $\left.37.0 \pm 0.5^{\circ} \mathrm{C}\right)$. After 48 hours of incubation, we cryodestroyed the cells, clarified and packed for storage at $-70^{\circ} \mathrm{C}$. The properties assessed were sterility of the resulting infecting preparation its infectious activity. We determined the SARS-CoV-2, variant B, experimental culture activity applying the negative colonies method and using a day old Vero C1008 cell culture monolayer (PFU/ml); another criterion was the virus' cytopathic effect $\left(\mathrm{CPE}_{50} / \mathrm{ml}\right)$. Sowing on a 10-fold solution on a universal selective thioglycolic medium allowed assessing presence of foreign microflora in the preparations made.

\section{Investigation of Mefloquine cytotoxicity to a Vero C1008 cell culture and antiviral activity against SARS-CoV-2 virus}

The studied Mefloquine lines were introduced into tubes containing Vero C1008 cell monolayer and incubated at $37.0 \pm 0.5^{\circ} \mathrm{C}$ for 120 hours. After the incubation, we evaluated cellular damage caused by the lines.

Results of the experiment indicate that all the studied lines of the drug show the same cytotoxicity in vitro. For the cell culture used, their $\mathrm{CPE}_{50}$ was $4.5 \mathrm{\mu g} / \mathrm{ml}$. At concentrations below $2.25 \mu \mathrm{g} / \mathrm{ml}$ the drug did not have a toxic effect on the cell culture, and at concentrations above $8.0 \mu \mathrm{g} / \mathrm{ml}$ it proved cytopathic to almost all cells of the monolayer. Thus, the maximum tolerated dose (MTD) of Mefloquine was $2.25 \mu \mathrm{g} / \mathrm{ml}$, and the range of concentrations for evaluation of its antiviral activity was $0.5-2.0 \mu \mathrm{g} / \mathrm{ml}$.

The results of investigation of effect of Mefloquine on the cytopathic activity of SARS-CoV-2, variant B, 24 hours postinfection are given in. The results were similar for all the drug lines tested.

The results obtained allow a conclusion that 24 hours after infection of the cells, cytopathic effect of the virus disappeared in case 0.5 to $2.0 \mu \mathrm{g} / \mathrm{ml}$ of Mefloquine were administered either before or after infection. In the control group, the cytopathic effect was $75 \%$.

The results of investigation of effect of Mefloquine on the cytopathic activity of SARS-CoV-2, variant B, 48 hours postinfection are given in

Forty-eight hours after infection of the cells, cytopathic effect of the virus disappeared in case $2.0 \mu \mathrm{g} / \mathrm{ml}$ of Mefloquine were administered after infection. In the control group, the cytopathic effect was 100\% (12/12). Administration of any of the studied doses of Mefloquine 1 hour before infection yielded no suppression of cytopathic activity of the virus. Doses of $1 \mu \mathrm{g} / \mathrm{ml}$ and $0.5 \mu \mathrm{g} / \mathrm{ml}$ administered 24 hours before infection caused $50 \%$ and $25 \%$ suppression of CPE, respectively.

The results of Mefloquine effect on virus reproduction in a cell culture are presented in. Ribavirin and Rebif ${ }^{\oplus}$ (Interferon $\beta 1 \alpha)$ were used as comparator drugs.

The results obtained indicate that $2.0 \mu \mathrm{g} / \mathrm{ml}$ of Mefloquine administered post-infection suppress reproduction of SARSCoV-2 virus at $1.7-1.9 \mathrm{lg}$, with the inhibition rate at about $99 \%$.

\section{CONCLUSION}

The results obtained confirm that $2 \mu \mathrm{g} / \mathrm{ml}$ of Mefloquine administered to the Vero $\mathrm{Cl008}$ cell culture 1 hour after introduction of SARS-CoV-2 completely block the effect of the virus within 2 days after infection. A day after infection, Mefloquine was registered to have antiviral effect when administered both 24 hours and 1 hour before and 1 hour after infection of the cell culture with SARS-CoV-2. As little as 0.5 $\mu \mathrm{g} / \mathrm{ml}$ of Mefloquine yielded $100 \%$ suppression of viral activity. The Mefloquine toxicity investigation showed that the drug exhibits a cytopathic effect on $50 \%$ of Vero Cl008 cells $\left(\mathrm{CPE}_{50}\right)$ at $4.5 \mu \mathrm{g} / \mathrm{ml}$. The maximum tolerated dose of Mefloquine is $2.25 \mu \mathrm{g} / \mathrm{ml}$.

Thus, the chemotherapeutic index (an indicator of the breadth of therapeutic effect, the ratio of its minimum effective dose to the maximum tolerated dose) for Mefloquine was $\geq 2$, which indicates a low specific activity of the drug. At the same time, it should be noted that the concentration at which Mefloquine becomes effective against SARS-CoV-2 can be accumulated when taking the drug in doses recommended for the prevention and treatment of malaria.

The generalized pharmacokinetic research data show that Mefloquine dose escalation in the range of 250-5001000-1500 mg (as provided in the Mefloquine Medical Use Guidelines) translates into an almost linear increase of its maximum concentration in blood plasma: 0.25- 0.43-0.8$1.22 \mu \mathrm{g} / \mathrm{ml}$, respectively, with the tmax value constant at 19.6 hours [20]. A one-time administration of Mefloquine in the doses of 750-1500 mg/day brings its maximum concentration in blood plasma to $1510 \mu \mathrm{g} / \mathrm{l}$ [21], while a course increases it 1.8-2.5 times [22]. Considering that the half-life of the drug is $15.5 \pm 10.4$ days, the concentration that ensures elimination of the virus can be achieved on the 2-3 day of administration, and it is maintained throughout the treatment period.

Table 1. Evaluation of antiviral activity of Mefloquine against the SARS-CoV-2, variant B, in a Vero C1008 cell culture, 24 hours after infection (infection dose 10 $\mathrm{CPE}, n=9)$

\begin{tabular}{|c|c|c|c|}
\hline \multirow{2}{*}{ Preparation } & Preparation concentration $\mu \mathrm{g} / \mathrm{ml}$ & CPE detection rate & CPE inhibition coefficient, \% \\
\hline \multirow{3}{*}{24 hours before infection } & 2 & $0 / 12$ & $>75$ \\
\cline { 2 - 4 } & 1 & $0 / 12$ & $>75$ \\
\cline { 2 - 4 } & 0.5 & $0 / 12$ & $>75$ \\
\hline \multirow{3}{*}{1 hour before infection } & 2 & $0 / 12$ & $>75$ \\
\cline { 2 - 4 } & 1 & $0 / 12$ & $>75$ \\
\cline { 2 - 4 } & 0.5 & $0 / 12$ & $>75$ \\
\cline { 2 - 4 } & 4 & $0 / 12$ & $>75$ \\
\cline { 2 - 4 } & 2 & $0 / 12$ & $>75$ \\
\cline { 2 - 4 } & 1 & $0 / 12$ & - \\
\hline
\end{tabular}


Table 2. Evaluation of antiviral activity of Mefloquine against the SARS-CoV-2, variant B, in a Vero C1008 cell culture, 48 hours after infection (infection dose 10 CPE, $n=9$ )

\begin{tabular}{|c|c|c|c|}
\hline Preparation & Preparation dose, $\mu \mathrm{g} / \mathrm{ml}$ & CPE detection rate & CPE inhibition coefficient, \% \\
\hline \multirow{3}{*}{24 hours before infection } & 2 & $12 / 12$ & 0 \\
\hline & 1 & $6 / 12$ & 50 \\
\hline & 0.5 & $9 / 12$ & 25 \\
\hline \multirow{3}{*}{1 hour before infection } & 2 & $12 / 12$ & 0 \\
\hline & 1 & $12 / 12$ & 0 \\
\hline & 0.5 & $12 / 12$ & 0 \\
\hline \multirow{3}{*}{1 hour after infection } & 2 & $0 / 12$ & 100 \\
\hline & 1 & $12 / 12$ & 0 \\
\hline & 0.5 & $12 / 12$ & 0 \\
\hline Infectious dose control & - & $12 / 12$ & - \\
\hline Medium control & - & $0 / 12$ & - \\
\hline
\end{tabular}

Table 3. Evaluation of antiviral activity of Mefloquine against the SARS-CoV-2, variant B, in a Vero C1008 cell culture, 48 hours after infection (infection dose 10 $\mathrm{CPE}, n=9)$

\begin{tabular}{|c|c|c|c|c|}
\hline Preparation & $\begin{array}{c}\text { Preparation dose, } \\
\mu \mathrm{g} / \mathrm{ml}\end{array}$ & $\begin{array}{c}\text { Virus accumulation level, } \\
\text { lg PFU/ml }\end{array}$ & $\begin{array}{c}\text { Virus accumulation level } \\
\text { drop, } \Delta \mathrm{lg}\end{array}$ & Inhibition coefficient, IC (\%) \\
\hline Mefloquine, series 010719 & 2.0 & $4.61 \pm 0.07$ & 1.83 & 98.93 \\
\hline Mefloquine, series 020719 & 2.0 & $4.50 \pm 0.09$ & 1.94 & 99.06 \\
\hline Mefloquine, series 030719 & 2.0 & $4.73 \pm 0.13$ & 1.71 & 98.83 \\
\hline \multirow{2}{*}{ Rebif $^{\infty}$ Interferon $\beta 1 \alpha$} & $10^{3}$ & $0.00 \pm 0.00$ & 6.44 & 100.00 \\
\hline & $10^{2}$ & $0.00 \pm 0.00$ & 6.44 & 100.00 \\
\hline Ribavirin, substance & 100 & $4.23 \pm 0.03$ & 2.21 & 99.38 \\
\hline Infection dose control & - & $6.44 \pm 0.09$ & - & - \\
\hline
\end{tabular}

It was established that Mefloquine concentration in internal organs and blood cells is over 5 times higher than that in blood plasma [23-24], and its concentration in the brain tissues can be
10-30 times greater than blood plasma concentration and reach $20 \mu \mathrm{M}$ [25]. Thus, in internal organs the drug may be eliminated as early as on the $1^{\text {st }}$ day after beginning of administration.

\section{References}

1. Antibodies against MERS coronavirus in dromedary camels, United Arab Emirates, 2003 and 2013. B. Meyer, M.A. Müller, V.M. Corman, et al. Emerg. Infect. Dis. 2014; 20(4): 552-559.

2. A novel coronavirus associated with severe acute respiratory yndrome. Ksiazek T.G., Erdman D, Goldsmith C.S., et al. N. Engl. J. Med. 2003; 348(20): 1947-1958.

3. Novel coronavirus infections in Jordan, April 2012: Epidemiological findings from a retrospective investigation. B. Hijawi, et al. East Mediterr Health J. 2013; 19: 12-18.

4. Isolation of a novel coronavirus from a man with pneumonia in Saudi Arabia. A.M. Zaki, et al. N. Engl. J. Med. 2012; 367: 1814-1820.

5. Human coronaviruses and other respiratory viruses: underestimated opportunistic pathogens of the central nervous system? Desforges M, Le Coupanec A, Dubeau P, Bourgouin A, Lajoie L, Dubé M, Talbot PJ., et al. Viruses. 2019 Dec pii: E14. doi: 10.3390/v12010014.

6. Chan KW, Wong VT2, Tang SCW1. COVID-19: An Update on the Epidemiological, Clinical, Preventive and Therapeutic Evidence and Guidelines of Integrative Chinese-Western Medicine for the Management of 2019 Novel Coronavirus Disease. Am J Chin Med. 2020; Mar 13: 1-26.

7. Biot, C., Daher, W., Chavain, N., Fandeur, T., Khalife, J., Dive, D., \& De Clerca, E. Design and Synthesis of Hydroxyferroquine Derivatives with Antimalarial and Antiviral Activities. Journal of Medicinal Chemistry. 2006; 49(9): 2845-2849.

8. Biot, C., Daher, W., Chavain, N., Fandeur, T., Khalife, J., Dive, D., \& De Clercq, E. Design and Synthesis of Hydroxyferroquine Derivatives with Antimalarial and Antiviral Activities. Journal of
Medicinal Chemistry. 2006; 49(9): 2845-2849.

9. De Wilde AH., Jochmans D., Posthuma CC. et al. Screening of an FDA-approved compound library identifies four small-molecule inhibitors of Middle East respiratory syndrome coronavirus replication in cell culture. Antimicrob Agents Chemother. 2014 Aug;58(8): 4875-84. doi: 10.1128/AAC.03011-14.

10. Liu J., Cao R., Xu M. et al.. Hydroxychloroquine, a less toxic derivative of chloroquine, is effective in inhibiting SARS-CoV-2 infection in vitro. Cell Discov. 2020; Mar 18: 6:16.

11. Yao X., Ye F., Zhang M. et al. In Vitro Antiviral Activity and Projection of Optimized Dosing Design of Hydroxychloroquine for the Treatment of Severe Acute Respiratory Syndrome Coronavirus 2 (SARS-CoV-2). Clin Infect Dis. 2020; Mar 9: pii: ciaa237.

12. Sun W., He S., Martínez-Romero C. et al. Synergistic drug combination effectively blocks Ebola virus infection. Antiviral Research. 2017; Jan 137: 165-172.

13. Balasubramanian, A., Teramoto, T., Kulkarni, A. A., Bhattacharjee, A. K., \& Padmanabhan, R. Antiviral activities of selected antimalarials against dengue virus type 2 and Zika virus. Antiviral Research. 2017; 137: 141-150.

14. McDonagh P., Sheehy PA., Norris JM. et al. Identification and characterisation of small molecule inhibitors of feline coronavirus replication. Vet Microbiol. 2014; Dec 5; 174(3-4): 438-447.

15. McDonagh P., Sheehy PA., Fawcett A., Norris JM. Antiviral effect of mefloquine on feline calicivirus in vitro. Vet Microbiol. 2015; Apr 17; 176(3-4): 370-7.

16. Fan $H_{H}$., Wang LQ., Liu WL. et al. Repurposing of clinically approved drugs for treatment of coronavirus disease 2019 in a 2019-novel coronavirus (2019-nCoV) related coronavirus model. 
Chin Med J (Engl). 2020 May 5; 133(9): 1051-1056.

17. Guidelines for the experimental (preclinical) study of new pharmacological substances [Rukovodstvo po jeksperimental'nomu (doklinicheskomu) izucheniju novyh farmakologicheksih veshhestv]. M.: Minzdrav RF, 2005. (in Russian).

18. Methodological approaches to the search for antiviral drugs, their testing and evaluation [Metodicheskie podhody $k$ poisku antivirusnyh preparatov, ih ispytanie i ocenka]. N.A. Lagutkin, N.I. Mitin, V.A. Starovojtova i dr. v kn. Viral inhibitors and their mechanism of action [Virusnye ingibitory $i$ mehanizm ih dejstvija] Pod red. V.P. Lozha, MK. Indulen, V.A. Kalnynja, N.A. Kanel' Riga, «Zinatne». 1977: 138-149. (in Russian).

19. Chizhov N.P., Ershov F.I., Indulin MK. The basics of experimental chemotherapy for viral infections [Osnovy jeksperimental'noj himioterapii virusnyh infekci]. Riga, 1988. (in Russian).

20. Desjardins RE, Pamplin CL 3rd, von Bredow J. et al. Kinetics of a new antimalarial, mefloquine. Clin Pharmacol Ther. 1979 Sep;26(3): 372-9.

\section{Литература}

1. Antibodies against MERS coronavirus in dromedary camels, United Arab Emirates, 2003 and 2013. B. Meyer, M.A. Müller, V.M. Corman, et al. Emerg. Infect. Dis. 2014; 20(4): 552-559.

2. A novel coronavirus associated with severe acute respiratory yndrome. Ksiazek T.G., Erdman D, Goldsmith C.S., et al. N. Engl. J. Med. 2003; 348(20): 1947-1958.

3. Novel coronavirus infections in Jordan, April 2012: Epidemiological findings from a retrospective investigation. B. Hijawi, et al. East Mediterr Health J. 2013; 19: 12-18.

4. Isolation of a novel coronavirus from a man with pneumonia in Saudi Arabia. A.M. Zaki, et al. N. Engl. J. Med. 2012; 367: 1814-1820.

5. Human coronaviruses and other respiratory viruses: underestimated opportunistic pathogens of the central nervous system? Desforges M, Le Coupanec A, Dubeau P, Bourgouin A, Lajoie L, Dubé M, Talbot PJ., et al. Viruses. 2019 Dec pii: E14. doi: 10.3390/v12010014.

6. Chan KW, Wong VT2, Tang SCW1. COVID-19: An Update on the Epidemiological, Clinical, Preventive and Therapeutic Evidence and Guidelines of Integrative Chinese-Western Medicine for the Management of 2019 Novel Coronavirus Disease. Am J Chin Med. 2020; Mar 13: 1-26.

7. Biot, C., Daher, W., Chavain, N., Fandeur, T., Khalife, J., Dive, D., \& De Clercq, E. Design and Synthesis of Hydroxyferroquine Derivatives with Antimalarial and Antiviral Activities. Journal of Medicinal Chemistry. 2006; 49(9): 2845-2849.

8. Biot, C., Daher, W., Chavain, N., Fandeur, T., Khalife, J., Dive, D., \& De Clercq, E. Design and Synthesis of Hydroxyferroquine Derivatives with Antimalarial and Antiviral Activities. Journal of Medicinal Chemistry. 2006; 49(9): 2845-2849.

9. De Wilde AH., Jochmans D., Posthuma CC. et al. Screening of an FDA-approved compound library identifies four small-molecule inhibitors of Middle East respiratory syndrome coronavirus replication in cell culture. Antimicrob Agents Chemother. 2014 Aug;58(8): 4875-84. doi: 10.1128/AAC.03011-14.

10. Liu J., Cao R., Xu M. et al.. Hydroxychloroquine, a less toxic derivative of chloroquine, is effective in inhibiting SARS-CoV-2 infection in vitro. Cell Discov. 2020; Mar 18: 6:16.

11. Yao X., Ye F., Zhang M. et al. In Vitro Antiviral Activity and Projection of Optimized Dosing Design of Hydroxychloroquine for the Treatment of Severe Acute Respiratory Syndrome Coronavirus 2 (SARS-CoV-2). Clin Infect Dis. 2020; Mar 9: pii: ciaa237.

12. Sun W., He S., Martínez-Romero C. et al. Synergistic drug combination effectively blocks Ebola virus infection. Antiviral Research. 2017; Jan 137: 165-172.

13. Balasubramanian, A., Teramoto, T., Kulkarni, A. A., Bhattacharjee,
21. Karbwang, J., Na-Bangchang, K. Clinical application of mefloquine pharmacokinetics in the treatment ofP falciparummalaria. Fundamental \& Clinical Pharmacology. 1994; 8(6): 491-502.

22. Ferreira MVD, Vieira JLF, Almeida ED. et al. Pharmacokinetics of mefloquine administered with artesunate in patients with uncomplicated falciparum malaria from the Brazilian Amazon basin. Malar J. 2018; Jul 16;17(1): 268.

23. Rozman RS, Molek NA, Koby R. The absorption, distribution, and excretion in mice of the antimalarial mefloquine, erythro2,8-bis(trifluoromethyl)-alpha-(2-piperidyl)-4-quinolinemethanol hydrochloride. Drug Metab Dispos. 1978 Nov-Dec; 6(6): 654-8.

24. Tao Y., Xue J., Jiang B. [et al.]. Significance of higher drug concentration in erythrocytes of mice infected with Schistosoma japonicum and treated orally with mefloquine at single doses. Parasitol Res. 2015 Dec; 114(12): 4521-30.

25. Pham YT, Nosten F, Farinotti R. et al. Cerebral uptake of mefloquine enantiomers in fatal cerebral malaria. Int $J$ Clin Pharmacol Ther. 1999 Jan;37(1): 58-61

A. K., \& Padmanabhan, R. Antiviral activities of selected antimalarials against dengue virus type 2 and Zika virus. Antiviral Research. 2017; 137: 141-150.

14. McDonagh P., Sheehy PA., Norris JM. et al. Identification and characterisation of small molecule inhibitors of feline coronavirus replication. Vet Microbiol. 2014; Dec 5; 174(3-4): 438-447.

15. McDonagh P., Sheehy PA., Fawcett A., Norris JM. Antiviral effect of mefloquine on feline calicivirus in vitro. Vet Microbiol. 2015; Apr 17; 176(3-4): 370-7.

16. Fan HH., Wang LQ., Liu WL. et al. Repurposing of clinically approved drugs for treatment of coronavirus disease 2019 in a 2019-novel coronavirus (2019-nCoV) related coronavirus model. Chin Med J (Engl). 2020 May 5; 133(9): 1051-1056.

17. Руководство по экспериментальному (доклиническому) изучению новых фармакологичексих веществ.-М., Минздрав PФ, 2005.

18. Методические подходы к поиску антивирусных препаратов, их испытание и оценка. Н.А. Лагуткин, Н.И. Митин, В.А. Старовойтова и др. в кн. Вирусные ингибиторы и механизм их действия Под ред. В.П. Ложа, МК. Индулен, В.А. Калныня, Н.А. Канель/ Рига, «Зинатне». 1977: 138-149.

19. Чижов Н.П., Ершов Ф.И., Индулин МК. Основы экспериментальной химиотерапии вирусных инфекций. Рига, 1988.

20. Desjardins RE, Pamplin CL 3rd, von Bredow J. et al. Kinetics of a new antimalarial, mefloquine. Clin Pharmacol Ther. 1979 Sep;26(3): 372-9.

21. Karbwang, J., Na-Bangchang, K. Clinical application of mefloquine pharmacokinetics in the treatment ofP falciparummalaria. Fundamental \& Clinical Pharmacology. 1994; 8(6): 491-502.

22. Ferreira MVD, Vieira JLF, Almeida ED. et al. Pharmacokinetics of mefloquine administered with artesunate in patients with uncomplicated falciparum malaria from the Brazilian Amazon basin. Malar J. 2018; Jul 16;17(1): 268.

23. Rozman RS, Molek NA, Koby R. The absorption, distribution, and excretion in mice of the antimalarial mefloquine, erythro2,8-bis(trifluoromethyl)-alpha-(2-piperidyl)-4-quinolinemethanol hydrochloride. Drug Metab Dispos. 1978 Nov-Dec; 6(6): 654-8.

24. Tao Y., Xue J., Jiang B. [et al.]. Significance of higher drug concentration in erythrocytes of mice infected with Schistosoma japonicum and treated orally with mefloquine at single doses. Parasitol Res. 2015 Dec; 114(12): 4521-30.

25. Pham $Y T$, Nosten F, Farinotti R. et al. Cerebral uptake of mefloquine enantiomers in fatal cerebral malaria. Int $\mathrm{J}$ Clin Pharmacol Ther. 1999 Jan;37(1): 58-61 